\title{
Best Practices of Solid Waste Management at Institute of Business Management, Karachi, Pakistan
}

\author{
Dr. Jamshaid lqbal ${ }^{1, *}$ \\ ${ }^{1}$ Department of Environment and Energy Management, Institute of Business Management, Karachi, Pakistan \\ *corresponding author: Jamshaid.iqbal@iobm.edu.pk
}

\section{Article Info}

Received:

15 March 2021

Accepted:

25 May 2021

Published:

1 August 2021

DOI:

Presented in The $6^{\text {th }}$ International (Virtual) Workshop on UI GreenMetric World University Rankings (IWGM 2020)

\begin{abstract}
Recently we conducted a study to evaluate the existing solid waste management practices at Institute of Business Management (IoBM), Karachi which shows that the institute possesses best management practices related to solid waste collection, transport, segregation, recycling/reuse, and final disposal. Adequate number of color-coded bins have been laid at appropriate locations throughout the university campus. Institute has enough staff for waste management including waste collection, transportation, and disposal. Results of our study indicate that about $2,033 \mathrm{~kg}$ of solid waste/month ( 24.5 tons/annum) is generated from the loBM campus. Out of the total, about $67.8 \%$ is the recyclable and reusable plastic, paper, and metal waste while, the remaining (about 32\%) is mostly organic waste generated from various facilities of the university. Economic analysis indicates that about 252,012 Pak rupees annually are earned from selling the recyclable and reusable inorganic solid waste. Study also indicate that about $500 \mathrm{~kg}$ of good quality compost per month can be prepared from the organic waste including food and yard waste that can be used for existing horticultural activities at the university. Moving towards a sustainable integrated solid waste management system necessitates improved system of waste collection, segregation, reselling, and composting.
\end{abstract}

\section{Keyword:}

Solid waste management, Recycling, Segregation, Compost

\section{Introduction}

Sustainable management of solid waste generated from educational institutes has become an emerging challenge in developing countries like Pakistan. It is mainly due to the lack of explicit environmental standards for institutional waste management. Currently in Pakistan the overall quantity and diversity of solid waste in educational institutes is rapidly increasing with the increase in number of students and staff. In view of several environmental and health issues, solid waste in educational institutes needs to be properly 
managed including collection, transportation, segregation, recycling, and disposal of solid waste.

Solid waste is defined as any unwanted non-liquid and non-gaseous material [1,2]. Based on the sources of generation, solid waste is categorized into three different types; municipal solid waste (MSW) including residential and commercial waste, Industrial waste mainly including the hazardous waste and, hospital waste which includes the infectious waste as major fraction [3].

Solid waste management (SWM) comprises the activities aiming to minimize the health, environmental and esthetic impact of the waste [4]. It includes the control of waste generation, storage, collection, transfer and transport, processing and disposal [5]. SWM is typically governed by the best principles of public health, economics, engineering, aesthetics and other environmental considerations [6]. Integrated Solid Waste Management (ISWM) is a comprehensive approach comprising the activities such as; waste prevention, recycling, composting, and disposal [7]. An effective ISWM system considers how to prevent, recycle, and manage solid waste in ways that most effectively protect human health and the environment keeping in view the economic considerations [8].

According to an estimate currently in Pakistan, about 48.5 million tons of solid waste are produced annually with an annual growth rate of 2.4 percent $[9,10]$. Out of the total waste generated approximately less than $50 \%$ is collected only from major metropolitan cities including, Karachi, Lahore, Islamabad, Gujranwala, Faisalabad and Rawalpindi. Waste collection in rural areas is almost non-existent in Pakistan [11]. In the absence of proper waste management system in Pakistan, most of the municipal waste is either burned or openly dumped at low lying areas potentially threatening the quality of surface and ground water as well as the health and welfare of the community [12].

Currently the number of higher education institutes (HEIs) in Pakistan is rapidly increasing with an increase in population [13]. Considering $0.45 \mathrm{~kg} / \mathrm{capita} /$ day national waste generation as reported by Pak EPA (11), approximately 300 tons of solid waste is daily generated from HEls in Pakistan which is about 2.5 percent of the total solid waste generated in the country. Currently the solid waste generated from higher education institutes in Pakistan is disposed of by city municipal authorities of the respective cities where $\mathrm{HEI}$ is located [14]. However, the collection and interim storage of the waste is sole responsible of the respective HEls [15].

Karachi is the largest city of Pakistan hosting about 40 higher education institutes including public, private and semi government universities and DAls [13]. Approximate amount of solid waste generating from HEls in Karachi is about 54 tons/day which is about 0.5 percent of the total waste generated from the city [16]. Similar to the rest of country solid waste from HEls in Karachi is also disposed of by Karachi Municipal Corporation (KMC), Sindh Solid Waste Management Board and Cantonment Boards from their respective jurisdictions [17]. However, the proper system of waste collection, transport, recycling and reuse is still very less common in HEls.

The present study aims to determine the existing practices of solid waste management including quantification and characterization of waste and identify the recycling and reusing potential and financial dynamics of solid waste management at the Institute of Business Management, Karachi (IoBM). Study highlights the best practices of solid waste management at the university and provide recommendations where required to achieve a sustainable system of integrated solid waste management by improving the existing system of waste collection, transport, segregation, recycling and reuse. 


\section{Materials and Methods}

This study encompasses both primary and secondary data sources. Primary data related to existing practices of solid waste management at loBM was collected through visits of various sources of solid waste generation at the university campus such as academic and administration buildings, cafeterias and student activity centers etc. From all facilities solid waste was collected on daily basis for the period of one month including both week days and weekends. Waste collected from all facilities was stored at central waste collection point located outside the university. At collection point waste was segregated to separate the various components including paper \& card board, plastic, metal and organic waste. Weights of segregated waste streams were measured with the help of a portable weighing balance. All types of waste collection and transfer were accomplished with the help of existing solid waste management staff and facilities being used at the university campus.

In addition to quantification and characterization of solid waste at university, visual observations were also made through regular visits of solid waste management facilities and existing practices including the placement of waste bins, color coding system and labeling of bins, waste transfer and transport facilities and health and safety measures adopted by the waste management staff particularly the waste collectors and transport personnel.

Existing practices of material use at university cafeteria by the students and staff were evaluated with the help of a survey questionnaire. Purpose of this questionnaire based survey was to evaluate the sustainability prospective for solid waste management at university i.e. to identify the recycling, reusable and waste reduction options. Key questions in this survey include; frequency of using cafeteria services, preferred mode of food consumptions, preference for plastic alternatives and general awareness about solid waste management practices at university.

Financial analysis was made to estimate the resalable potential of various recyclable waste items such as plastic, metal, Styrofoam plates, disposable glasses and juice boxes etc. For the organic waste, composting potential was evaluated. MS excel software was used for data processing and statistical analysis during this study.

\section{Results and Discussions}

\subsection{Existing system of solid waste management}

Currently the maximum number of students and staff of the university use paper plates as preferred food serving dish whereas, the use of plastic and ceramic plates is only about $20 \%$ and $25 \%$ respectively (fig.1). Reuseable plates for food serving should be used at maximum so as to minimize the waste production at source. This needs regular trainings and awareness sessions for students and staff related to waste minimization, reuse and recyclying as well as the potential health and environmental impacts of solid waste.

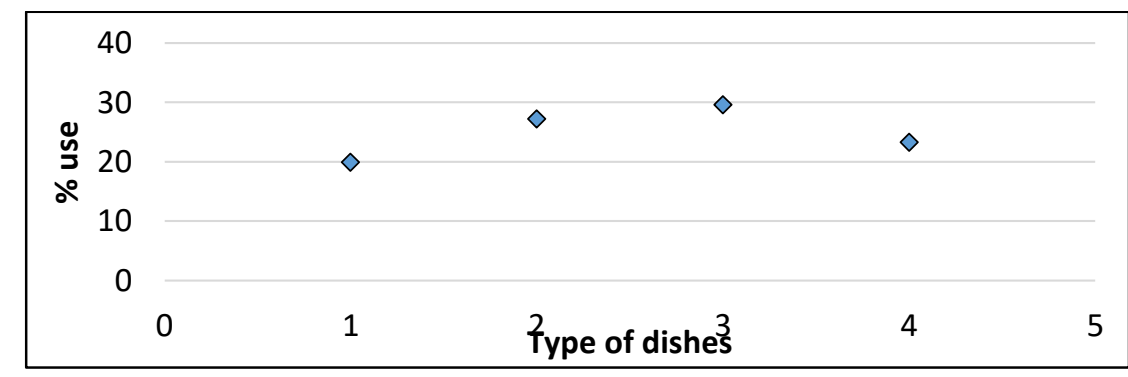

Figure 1. Preferred food serving dishes at university cafeteria 
Plastic bottles are the preferred mode of dink consumption (38.3\%) among the students and staff of university as shown in figure 2 , whereas, the use of steel cans is only $17 \%$. As can be seen in figure 1, currently the use of Styrofoam cup for tea and drink consumption is also significantly high at the university.

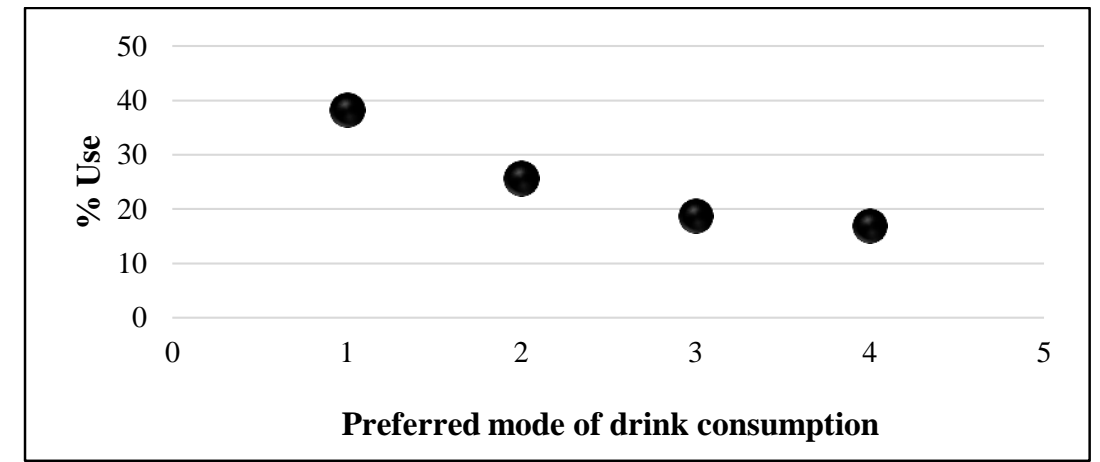

Figure 2. Preferred mode of drinking at Institute of Business Management

Currently the solid waste is collected from all facilities with the help of trash bins placed in each room and office of the university. In addition, outside each facility, large moveable bins with proper color coding have also been placed. Waste from small bins is shifted to the large bins once in a day. Although the color coded bins have been placed throughout the university campus yet, the use of color bins is not quite common and most of the time, mixed waste is found in the colored bins. It is noted that during the recent years the use of color coded bins has significantly improved among the students and staff however, it still needs to be improved through regular trainings and seminars related to sustainable solid waste management including the proper use of color coded bins as reported by various research studies in Pakistan $[18,19]$.

Waste collected from all facilities of the university is transported to a temporary waste storage point located outside the university. At this point manual segregation of the waste is undertaken by local vendors who separate various useful items from waste stream mainly including plastic, metal and paper to be sold in local market. After segregation the remaining waste mainly comprises the organic part which is thrown into a nearby open waste dumpsite. As the current practice, sold waste is given to the vendor free of any cost and he does not provide any services related to waste collection and transportation to temporary storage point. The only service he provides is to take off the recyclable waste from the waste collection point. This situation can be improved by properly segregating and selling out the recyclable waste which may be a reasonable input in overall integrated solid waste management system as proposed through this study and reported by Sadef et al [20].

As far as the organic waste is concerned it should be used for composting that can be used for horticultural practices at university [21]. As determined by this study there is the significant potential and sufficient space available for composting outside the university campus.

\subsection{Waste quantification and characterization}

Solid waste collected from various facilities of the university was segregated into four components including paper and cardboard, plastic, metal and organic waste. Monthly average and percentage of each component waste is provided in in table 1. 
Table 1. Monthly waste generated from various facilities of the loBM

\begin{tabular}{l|l|l|l|l|l|c}
\hline Waste & \multicolumn{6}{c}{ Weight (kg) } \\
\cline { 2 - 8 } & $\begin{array}{l}\text { component } \\
\text { flocks }\end{array}$ & $\begin{array}{c}\text { Administrat } \\
\text { ion block }\end{array}$ & $\begin{array}{c}\text { Cafeteria and } \\
\text { student } \\
\text { activity } \\
\text { center }\end{array}$ & $\begin{array}{c}\text { Other areas } \\
\text { (library, } \\
\text { parking, } \\
\text { yards) }\end{array}$ & Total & $\begin{array}{c}\text { \% of } \\
\text { total } \\
\text { waste }\end{array}$ \\
\hline $\begin{array}{l}\text { Paper and } \\
\text { cardboard }\end{array}$ & 192.8 & 64.1 & 78.4 & 53.6 & 388.9 & 19.1 \\
$\begin{array}{l}\text { Plastic } \\
\text { Metal }\end{array}$ & 342.4 & 19.5 & 128.6 & 48.2 & 538.7 & 26.5 \\
$\begin{array}{l}\text { Organic } \\
\text { Grand Total }\end{array}$ & 278.2 & 32.0 & 86.4 & 55.0 & 451.6 & 22.2 \\
\hline
\end{tabular}

As shown in table 1, in addition to the organic waste, overall waste stream generated from the university occupies the significant proportion of paper, plastic and metal which are the potential recyclable items in Pakistan and can easily be sold out in local market at established scrap rates. Sold out recyclable material in Pakistan is sent back to various recycling and manufacturing industries where it is recycled into various items [22]. The highest amount of organic waste is generated from student cafeteria and activity center which is mostly the food and kitchen waste generated during cooking and eating the meals. This type of organic waste can be used to prepare the compost having potential application as organic fertilizer.

\subsection{Economic analysis}

A simplified economic assessment of the resalable solid waste for the period of one month and one year is provided in the table 2 . Unit rates provide in the table 2 are based on unsolicited vendor rates currently established in the city.

Table 2. Economic analysis of various types of waste generated from university

\begin{tabular}{l|l|l|l|l|l}
\hline \multicolumn{1}{c|}{ Waste type } & \multicolumn{2}{c}{ Weight (kg) } & $\begin{array}{c}\text { Price/kg } \\
\text { (PKRs) }\end{array}$ & \multicolumn{2}{c}{$\begin{array}{c}\text { Total amount } \\
\text { (PKRs) }\end{array}$} \\
\hline & Monthly & Annual & & Monthly & Annual \\
\hline Plastic & 538.7 & 6,464 & 15 & 8,080 & 96,960 \\
Metal & 451.6 & 5,419 & 20 & 9,032 & 108,384 \\
Paper and cardboard & 388.9 & 4,667 & 10 & 3,889 & 46,668 \\
\hline Total & $\mathbf{1 3 7 9 . 2}$ & $\mathbf{1 6 , 5 5 0}$ & & $\mathbf{2 1 , 0 0 1}$ & $\mathbf{2 5 2 , 0 1 2}$ \\
\hline
\end{tabular}

The cost of resalable waste calculated in table 2 reflects the cost gained without any additional effort i.e. by using the existing system of solid waste management at the university. However, if the recyclable solid waste is properly sold out through some certified scrap merchant, the overall economic gain can be significantly increased and the income generated can be utilized to achieve a self-sustained SWM system at the university. 


\subsection{Composting analysis}

Boldrin et al. reported a mass reduction of about 11-35 \% (average: 23\%) during the composting of generalized organic waste [23]. Based on this, about $500 \mathrm{~kg}$ of good quality compost can be produced per month from the organic waste generated from various facilities of the university. Besides its use as organic fertilizer, the composting also reduces the overall volume of the organic waste up to $41 \%$ [24]. Carbon and nitrogen losses from organic waste during the composting process accounts for about $29 \%$ and $49 \%$ respectively [25]. The compost prepared from university waste can be used for horticultural practices at the campus saving the amount to be used to purchase the fertilizer from market.

\section{Conclusions}

Analysis of existing solid waste management system at the loBM, including the quantification and characterization of waste reveals that currently an acceptable system of SWM is in practice at this higher education institute with sufficient facilities of waste collection, transportation, segregation and disposal. However, it still needs improvements. According to the results of this study, about 252,012 Pak Rupees can be generated from reselling the $16,550 \mathrm{~kg}$ of total recyclable waste generated from the university. Income generated from the waste, can be used to run the various activities of SWM the university such as to purchase the waste bins, personal protection equipment for the waste staff and for many other expenses. Composting of organic waste should be started by utilizing the space available at existing waste collection site outside the university. Overall the findings of this study reveal that there is significant potential to move towards a self-sustained integrated system of solid waste management at the university which can be achieved by implementing the proper system of waste collection, segregation, waste reselling and composting as suggested by this study.

\section{References}

1. Narayana T. Municipal solid waste management in India: From waste disposal to recovery of resources. Waste management. 2009 Mar 1;29(3):1163-6.

2. Babayemi JO, Dauda KT. Evaluation of solid waste generation, categories and disposal options in developing countries: a case study of Nigeria. Journal of Applied Sciences and Environmental Management. 2009;13(3).

3. Meng X, Tan X, Wang Y, Wen Z, Tao Y, Qian Y. Investigation on decision-making mechanism of residents' household solid waste classification and recycling behaviors. Resources, Conservation and Recycling. 2019 Jan 1; 140:224-34.

4. Hoornweg D, Bhada-Tata P. What a waste: a global review of solid waste management. World Bank, Washington, DC; 2012 Mar 15.

5. McDougall FR, White PR, Franke M, Hindle P. Integrated solid waste management: a life cycle inventory. John Wiley \& Sons; 2008 Apr 15.

6. Guerrero LA, Maas G, Hogland W. Solid waste management challenges for cities in developing countries. Waste management. 2013 Jan 1;33(1):220-32.

7. Asefi $\mathrm{H}$, Lim S. A novel multi-dimensional modeling approach to integrated municipal solid waste management. Journal of cleaner production. 2017 Nov 10; 166:1131-43.

8. Marshall RE, Farahbakhsh K. Systems approaches to integrated solid waste management in developing countries. Waste management. 2013 Apr 1;33(4):988-1003. 
9. Ali M, Marvuglia A, Geng Y, Chaudhry N, Khokhar S. Emergy based carbon footprinting of household solid waste management scenarios in Pakistan. Resources, Conservation and Recycling. 2018 Apr 1; 131:283-96.

10. Solid Waste Management in Pakistan by Rachael Lew | April 8, 2019: https://www.bioenergyconsult.com/solid-waste-management-in-pakistan.

11. Pakistan environment protection agency, Brief on solid waste management in Pakistan, 2013: http://environment.gov.pk/images/environmentalissues/BriefSWMPak.pdf

12. Iqbal J, Javed A, Baig MA. Growth and nutrient removal efficiency of duckweed (lemna minor) from synthetic and dumpsite leachate under artificial and natural conditions. PloS one. 2019;14(8).

13. Higher Education Commission of Pakistan, HEC Recognized Universities and Degree Awarding Institutions 2019: https://www.hec.gov.pk/english/universities/pages/recognised.aspx

14. Haider A, Amber A, Ammara S, Mahrukh KS, Aisha B. Knowledge, perception and attitude of common people towards solid waste management-a case study of Lahore, Pakistan. International Research Journal of Environment Sciences. 2015;4(3):100-7.

15. Mahar A, Malik RN, Qadir A, Ahmed T, Khan Z, Khan MA. Review and analysis of current solid waste management situation in urban areas of Pakistan. InProceedings of the international conference on sustainable solid waste management 2007 Sep; Vol. 8, p. 36.

16. Mahmood H, Khan MM. Urban Solid Waste Management in Karachi, Pakistan. International Journal of Economic and Environmental Geology. 2019 May 24;10(1):7883.

17. Ali M, Olley J, Cotton A. Agents of change: the case of Karachi City's waste management. Third World Planning Review. 1998 Aug 1;20(3):255.

18. Nisar, H., Ejaz, N., Naushad, Z., \& Ali, Z. (2008). Impacts of solid waste management in Pakistan: a case study of Rawalpindi city. WIT Transactions on Ecology and the Environment, 109, 685-691.

19. Batool, S. A., \& Chuadhry, M. N. (2009). The impact of municipal solid waste treatment methods on greenhouse gas emissions in Lahore, Pakistan. Waste management, 29(1), 63-69.

20. Sadef Y, Nizami AS, Batool SA, Chaudary MN, Ouda OK, Asam ZZ, Habib K, Rehan M, Demirbas $A$. Waste-to-energy and recycling value for developing integrated solid waste management plan in Lahore. Energy Sources, Part B: Economics, Planning, and Policy. 2016 Jul 2;11(7):569-79.

21. Farrell $\mathrm{M}$, Jones DL. Critical evaluation of municipal solid waste composting and potential compost markets. Bioresource technology. 2009 Oct 1;100(19):4301-10.

22. Batool SA, Chaudhry N, Majeed K. Economic potential of recycling business in Lahore, Pakistan. Waste management. 2008 Jan 1;28(2):294-8.

23. Boldrin A, Christensen TH, Körner I, Krogmann U. Composting: mass balances and product quality. InSolid Waste Technology and Management 2011. Wiley.

24. Breitenbeck GA, Schellinger D. Calculating the reduction in material mass and volume during composting. Compost science \& utilization. 2004 Sep 1;12(4):365-71.

25. Tiquia SM, Richard TL, Honeyman MS. Carbon, nutrient, and mass loss during composting. Nutrient cycling in Agroecosystems. 2002 Jan 1;62(1):15-24. 